\title{
Is there a Gay Advantage in Creativity?
}

\author{
Amelia Mohd Noor ${ }^{1}$, Chew Sim Chee ${ }^{1} \&$ Aslina Ahmad ${ }^{1}$ \\ ${ }^{1}$ Department of Psychology and Counseling, Faculty of Education and Human Development, Sultan Idris \\ Education University, Malaysia \\ Correspondence: Chew Sim Chee, Department of Psychology and Counseling, Faculty of Education and Human \\ Development, Sultan Idris Education University, 35900 Tanjong Malim, Perak, Malaysia. E-mail: \\ chee@fppm.upsi.edu.my
}

\author{
Received: February 5, $2013 \quad$ Accepted: April 16, $2013 \quad$ Online Published: May 14, 2013 \\ doi:10.5539/ijps.v5n2p32 \\ URL: http://dx.doi.org/10.5539/ijps.v5n2p32
}

\begin{abstract}
Common speculations hold that homosexual individuals can be more creative, considering the overrepresentation of homosexuals in the artistic and creative pursuits. The few past studies available did not find evidence to support this contention. However, research has found gender differences in creativity indicating girls being more creative. If gay males share more female-typical personality traits, it would be interesting to ask if this would be reflected in any difference in creativity between homosexuals and heterosexuals. The present study thus aimed to disentangle the association between creativity and sexual orientation. A total of 38 homosexual males (mean age $=31.6$ years, S.D. $=9.7$ years) and 34 heterosexual males (mean age $=21.8$ years, S.D. $=4.3$ years) participated. All participants completed an online survey on creativity (using Khatena-Torrance Creative Perception Inventory) and sexual orientation (using the adapted Klein Sexual Orientation Grid). A one-way between -groups multivariate analysis of variance was conducted to examine differences in creative perception as a function of sexual orientation. The results indicated that there was no significant difference for each of the dimensions of creativity perception between homosexual and heterosexual males. The present findings were compatible with previous studies that homosexuals are no more or less creative. A distinction between actual and self-perceived creativity however, should also be noted.
\end{abstract}

Keywords: creativity, homosexuality, sexual orientation

\section{Introduction}

Studies on creativity have received considerable interest in various interdisciplinary fields. Scholars have attempted to define creativity based on theoretical framework or the context of study conducted. Creativity is a natural process (Torrance, 1993) that arises from an individual (Amabile, 1998) in response to something missing or incomplete. Creativity may not be fully captured or defined in words, but one can perhaps at least begin to indicate what it is albeit in an indirect way (Bohm, 1968). Gedo (1996) describes creativity as major, original accomplishments in difficult endeavors which cannot be correlated to any specific personality attributes. According to Kaufman and Baer (2010), the various definitions of creativity primarily center on two core elements i.e., novelty and appropriateness to the task or problem being addressed. In essence, creativity requires both originality and effectiveness of its application.

As the definitions of creativity evolve to become more multi-faceted, much studies have been conducted on the subject of creativity in relation to gender (Ai, 1999; Baer, 1997; Charyton, Basham, \& Elliot, 2008; Gedo, 1996; Kaufman, Baer, Agars, \& Loomis, 2010; Kaufman, 2006, Stoltzfus, Nibbelink, Vredenburg, \& Thyrum, 2011), personality (Lippa, 2005; Norlander, Erixon, \& Archer, 2000), academic achievement (Ai, 1999; Habibollah, Abdullah, Tengku, Sharir, \& Kumar, 2010; Palaniappan, 2007; Palaniappan, 1994), extrinsic rewards (Baer, Oldham, \& Cummings, 2003), ethnicity (Kaufman et al., 2010; Kaufman, 2006), social identity (Adarves-Yorno, Postmes, \& Haslam, 2006) as well as environmental impact (Hennessey, 1995; 2003).

Nonetheless, research focusing on sexual orientation and its relation to creativity has been limited. One of the first few studies that examined this came from Ellis (1959) which reported that heterosexuals were more creative than homosexuals. Nonetheless, this study has been criticized on its generalizability as the samples consisted of clinical patients undergoing psychopathological treatment. A later study by Domino (1977) however, did not find any support for the contention that homosexuals are more creative. Other studies (e.g., Gautam, 2001; Konik \& 
Crawford, 2004; Lippa, 2005) have measured creativity in gay men and lesbian women but looking at gender differences.

Other studies focusing on perceptions toward homosexuality (Anderssen, 2002; Çirakoğlu, 2006, Chao, Wang, \& Gao, 2010; Whitley, 1990) reported a more rejecting and negative attitude toward homosexuality. Such stigma can be long-lasting and is likely to persist in the future (Cadwell,1991 in Hart, 2004). There needs to be a shift in paradigm from the disease model of homosexuality to studying the positive functioning of sexual minority. This would be a more balanced approach in the studies regarding homosexual individuals (Brown, 1989) and by addressing the missing gaps in other related aspects of homosexuals (Singh \& Shelton, 2011; Voorhis \& Wagner, 2002; Yarhouse, 2012).

Homosexuality has been considered as a unique fusion of masculine and feminine traits (Fassler, 1979) and common stereotypes hold that gay males are more feminine than heterosexual males (Lippa, 2005). It follows that there exists the speculation that homosexuals can be more artistic and creative than heterosexuals (Brown, 1989; Ellis, 1959; Konik \& Crawford, 2004). It is not unreasonable to speculate that there could be a link between homosexuality and creativity (Stokinger, 1974) which also tends to be enhanced with nurturing, understanding, respect, opportunities, and freedom.

Consider the overrepresentation of homosexuals in the artistic and creative pursuits such as in the field of writing, acting, music, painting, and the like, it is not unreasonable as to speculate that gay people could be more artistically inclined (Gautam, 2001). Nonetheless, the dearth of research on creativity and homosexuality has not established a link between the two (Domino, 1977; Gautam, 2001). On the other hand, research has found gender differences in creativity with girls being more creative than boys (Cheung \& Lau, 2010). If gay men share a more female-typical personality traits (e.g., Lippa, 2008), will this also be similarly reflected as in the previous finding on the gender differences in creativity? It is also important to note that creativity is multifaceted (e.g., Fishkin \& Johnson, 1998) and that different measures could have tapped into the different elements of creativity, hence the inconsistent findings.

In light of the lack of empirical studies that are still needed to clarify differences in creativity based on sexual orientation, this study thus aimed to explore and examine the possible differences of creativity as a function of sexual orientation. We hypothesized that homosexual males would score higher than heterosexuals on creativity.

\subsection{Research Question}

Is there a difference in perceived creativity based on sexual orientation?

1.2 Hypothesis

There is a higher level of perceived creativity in homosexual males compared to heterosexual males.

\section{Method}

\subsection{Participants}

Participants consisted of 72 males who participated voluntarily by completing a set of questionnaire hosted online. Of all participants, 38 were homosexual males (mean age $=31.6$, S.D. $=9.7$ years) and 34 were heterosexual males (mean age $=21.8$, S.D. $=4.3$ years).

\subsection{Procedures}

This study involved completing a set of self-reported measures and questionnaire hosted online. Participants read the explanatory statement about the study before proceeding to complete the questionnaire. This research did not require any identification information and participants of this research would remain anonymous.

\subsection{Stimuli}

The Klein Sexual Orientation Grid (American Institute of Bisexuality, 2007). A simplified item was used to indicate a person's sexual orientation based on a 6-point Likert scale (i.e., 1 - exclusively homosexual, 2 mainly homosexual, 3 - little more sexual, 4 - little more heterosexual, 5 - mainly heterosexual, 6 - exclusively heterosexual). This is further regrouped into homosexual (scale 1-3) and heterosexual (scale 4-6) groups.

Khatena-Torrance Creative Perception Inventory (KTCPI) (Khatena \& Torrance, 1976). KTCPI consists of two separate tests of creative self-perceptions i.e., What Kind of Person Are You (WKOPAY?) and Something About Myself (SAM) measuring different dimensions of the creative personality (Khatena \& Torrance, 1998). The KTCPI has been reported to have good reliabilities and validity (Palaniappan, 1994). Habibollah et al. (2010) found that it showed a good reliability in assessment of creativity both for WKOPAY (alpha $=0.775$ ) and SAM $($ alpha $=0.779)$. 
What Kind of Person Are You (WKOPAY?). WKOPAY is a creative personality measure based on the rationale that an individual has a psychological self whose structures have incorporated both creative and non-creative ways of behaving (Torrance, 1993; Palaniappan, 2010). The WKOPAY has 50 items. Two choices are served as $a$ and $b$ in each item and they are forced-choice. In some cases, an item calls for a choice between two socially desirable characteristics, and in others, two socially undesirable characteristics. Similarly, there are items that call for choices between two characteristics that differentiate between creative and relatively noncreative people. Responses to each item are scored 1 or 0 . Total scores range from 0 to 50 on the complete scale of 50 items. All blank responses are scored zero. According to Khatena and Torrance (1998), the score can be interpreted based on five factors as below.

Acceptance of Authority (Factor I). It relates to being obedient, respectful and polite, and to following rules and accepting others in power.

Self-Confidence (Factor II). It relates to being sure of one-self and full of energy, getting along well with others, wanting to learn or know, finishing the task at hand, and remembering well.

Inquisitiveness (Factor III). It relates to always asking questions, feeling strong emotions, talking a lot, demanding recognition and insisting on rights, and being obedient.

Awareness of Others (Factor IV). It relates to being respectful and polite, popular or well-liked and caring, getting along well with others, and preferring to work in a group.

Disciplined Imagination (Factor V). It relates to being full of energy, imaginative and never bored, trying difficult tasks, preferring task that are challenging, not giving up easily, finishing the task at hand, working hard, and seeking adventure.

Something About Myself (SAM). SAM measures creative perception based on the rationale that creative behavior is reflected in an individual's personal creative characteristics possessed and in engaging in creative thinking and creative productions (Khatena, 1976; Palaniappan, 2010). SAM has 50 items. Each of the check-marked responses is awarded with one point and zero for each blank response. Thus, the more the score, the higher the level of perceived creativity indicated. The total score ranges from 0 to 50 based on six factors as described below (Palaniappan, 2010).

Environmental Sensitivity (Factor I). It relates to being open to ideas of others, relating ideas to what can be seen, touched, or heard; interest in beautiful and humorous aspects of experiences and sensitivity to meaningful relations.

Initiative (Factor II). It relates to directing, producing and/or playing leads in dramatic and musical productions; producing new formulas or new products; and bringing about changes in procedures or organization.

Self-Strength (Factor III). It relates to self-confidence in matching talents against others, resourcefulness, versatility, willingness to take risks, desire to excel, and organizational ability.

Intellectuality (Factor IV). It relates to intellectual curiosity, enjoyment of challenging tasks, imagination, and preference for adventure over routine, liking for reconstruction of things and ideas to form something different, and dislike for doing things in a prescribed routine.

Individuality (Factor V). It relates to preference for working by oneself rather than in a group, seeing oneself as a self-starter and somewhat eccentric, critical of others' work, thinking for oneself, working for long periods without getting tired.

Artistry (Factor VI). It relates to production of objects, models, paintings, carving, musical composition, receiving awards or prizes or having exhibits, production of stories, play, poems and other literary pieces.

\subsection{Data Analysis}

A one-way between-groups multivariate analysis of variance was performed to investigate differences in creative perception as a function of sexual orientation. 


\section{Results}

Table 1. Educational level of participants

\begin{tabular}{lcc}
\hline Highest Level of Education & \multicolumn{2}{c}{ Sexual Orientation } \\
& Homosexuals & Heterosexuals \\
\hline No formal qualification & 0 & 1 \\
Primary & 1 & 1 \\
Secondary & 7 & 3 \\
Tertiary & 30 & 29 \\
Total & $\mathbf{3 8}$ & $\mathbf{3 4}$ \\
\hline
\end{tabular}

It can be seen from Table 1 that the educational level of homosexual participants closely matched the heterosexual participants, with the majority having a tertiary education in this sample.

Table 2. Mean and standard deviation on creativity according to sexual orientation

\begin{tabular}{lllll}
\hline KTCPI & \multicolumn{2}{l}{ Homosexuals } & \multicolumn{2}{l}{ Heterosexuals } \\
& Mean & SD & Mean & SD \\
\hline What Kind of Person Are You (WKOPAY) & & & & \\
Acceptance of Authority & 2.79 & 2.00 & 2.65 & 2.19 \\
Self-Confidence & 5.34 & 2.02 & 5.94 & 1.69 \\
Inquisitiveness & 2.97 & 1.55 & 2.71 & 1.82 \\
Awareness of Others & 6.18 & 1.56 & 6.26 & 1.80 \\
Disciplined Imagination & 4.63 & 2.26 & 4.88 & 2.25 \\
& & & & \\
Something About Myself (SAM) & & & & \\
Environmental Sensitivity & 5.40 & 0.97 & 5.38 & 0.70 \\
Initiative & 3.39 & 1.39 & 3.44 & 1.64 \\
Self-Strength & 7.45 & 1.70 & 7.56 & 1.65 \\
Intellectuality & 7.45 & 2.13 & 8.03 & 1.34 \\
Individuality & 4.66 & 1.02 & 4.59 & 1.05 \\
Artistry & 2.26 & 1.61 & 1.82 & 1.53 \\
\hline
\end{tabular}

A one-way between -groups multivariate analysis of variance was conducted to examine differences in creative perception as a function of sexual orientation. Preliminary assumption on normality was tested with no serious violations noted. There was no significant effect of sexual orientation on the combined dependent variables of creative perception, $F(11,60)=1.20, p>.05$; Wilk's Lambda $=.84$; partial $\eta^{2}=.16$.

\section{Discussion}

In the present study, we examined the differences of creative perception comparing between homosexual and heterosexual males. Our results indicated that there was no significant difference between both groups for each of the dimensions of creativity perception. Hence, the hypothesis of this study was not supported. The findings are compatible with Domino's (1977) that homosexuals are no more or less creative than heterosexuals. This was also consistent with Konik and Crawford's study (2004) on the cognitive flexibility (a domain of normative creativity) of homosexual and heterosexual participants, which found that there was no significant difference between the two groups. According to Kaufman (2006), it is unclear if people conceive of creativity as the same constructs across all domains which may result in some degree of variability. 
The perceptions of creativity depend not just on intrinsic properties, but also on features of the context and the perceiver (Csikszentmihalyi, 1998 in Adarvers-Yorno et al., 2006). Lippa (2005) posited that many gay men, like most heterosexual men, do not like to be labeled as 'feminine' or 'effeminate'. Thus, there could be a possibility that homosexual male participants did not rate themselves in objective way, shifting their self-reported creative perception in the more socially desirable direction, consciously or unconsciously. This might result in the more average level of creativity. In addition, Lippa (2005) found that older gay men samples, on average, rated themselves as less feminine and more masculine than younger gay men did. The homosexual participants in this study were somewhat older than the heterosexual participants which might also be taken into account in the interpretation of the non-significant findings.

Moreover, Gedo (1996) argued that assessments of creative success involve social judgments. It can be said that creativity is a talent taken from the complex interaction of heritage and environment (Ghafourian, 2012). Whatever an individual's particular talents, skills and creative thinking abilities, the conditions under which they work and live in can significantly impact on the level of creativity produced (Hennessey, 2003). In other words, the impact of environment on creativity is significant and highly complex. Due to this social-environmental influence, like heterosexual males in general, gay males are similarly socialized throughout much of their lives to adopt the ideal of masculinity (Lippa, 2005). In our present context, people tend to group together more by their professionalism than by sexual orientation. This means that homosexual and heterosexual males are more likely to work or live together in one social setting. Therefore, there are greater opportunities for them to facilitate creative exchanges with each other in order to accomplish their shared task or common goals. One's homosexual orientation does not seem to confer any advantage nor disadvantage when it comes to creativity. Both homosexual and heterosexual males are non-differentiable in creativity.

Overall, the result of this study showed that neither homosexual participants nor heterosexual participants scored higher on creativity, including creative to non-creative ways of behaving and their self-characteristics. However, it is important to note that self-perceptions of creativity do not equal the actual creativity (Kaufman, 2006). Future research will benefit from the use of a battery of measures which will be more objective to capture creativity and a larger sample size. It will also be interesting to extend the current research to studying creativity in other sexual minorities including lesbian, bisexual, and transgender individuals to give a richer understanding.

\section{Acknowledgements}

This study was funded by a university grant (code: 2011-0127-106-01) from Research Management Centre, Sultan Idris Education University, Malaysia. We would like to thank Song Yee Yew, Maggie Yeo Wan Yin, and Cham Chin Hong for assistance with data collection. We are grateful for all participants who took part in this study.

\section{References}

Adarves-Yorno, I., Postmes, T., \& Haslam, S. A. (2006). Social identity and the recognition of creativity in groups. British Journal of Social Psychology, 45, 479-497. http://dx.doi.org/10.1348/014466605X50184

Ai, X. (1999). Creativity and academic ahievement: An investigation of gender differences. Creativity Research Journal, 12(4), 329-337. http://dx.doi.org/10.1207/s15326934crj1204_11

Amabile, T. (1998). How to kill creativity. Havard Bussiness Review, 77-87.

American Institute of Bisexuality. (2007). The Klein Sexual Orientation Grid. Retrieved August 11, 2011, from $\mathrm{http}: / /$ www.bisexual.org/kleingrid.html

Anderssen, N. (2002). Does contact with lesbian and gays lead to friendlier attitudes? A two year longitudinal study. Journal of Community and Applied Social Psychology, 12, 124-136. http://dx.doi.org/10.1002/casp.665

Baer, J. (1997). Gender differences in the effects of anticipated evaluation on creativity. Creativity Research Journal, 10(1), 25-31. http://dx.doi.org/10.1207/s15326934crj1001_3

Baer, M., Oldham, G. R., \& Cummings, A. (2003). Rewarding creativity: When does it really matter? The Leardership Quarterly, 14, 569-586. http://dx.doi.org/10.1016/S1048-9843(03)00052-3

Bohm, D. (1968). On creativity. Leonardo, 1(2), 137-149. http://dx.doi.org/10.2307/1571951

Brown, L. S. (1989). New voices, new visions: Toward a lesbian/gay paradigm for psychology. Psychology of Women Quarterly, 13, 445-458. http://dx.doi.org/10.1111/j.1471-6402.1989.tb01013.x

Chao, H., Wang, P., \& Gao, Y. (2010). A survey of Chinese unversity students' perceptions of and attitudes 
towards homosexuality. Social Behavior and Personality, 38(6), 721-728. http://dx.doi.org/10.2224/sbp.2010.38.6.721

Charyton, C., Basham, K. M., \& Elliot, J. O. (2008). Examining gender with general creativity and preferences for creative persons in college students within the science and the arts. Journal of Creative Behavior, 42(3), 216-222. http://dx.doi.org/10.1002/j.2162-6057.2008.tb01296.x

Cheung, P. C., \& Lau, S. (2010). Gender differences in the creativity of Hong Kong school children: Comparison by using the new electronic Wallach-Kogan Creativity Tests. Creativity Research Journal, 22, 194-199. http://dx.doi.org/10.1080/10400419.2010.481522

Çirakoğlu, O. C. (2006). Perception of homosexuality among Turkish university students: The roles of labels, gender, and prior contact. The Journal of Social Psycholog, 146(3), 293-305. http://dx.doi.org/10.3200/SOCP.146.3.293-305

Domino, G. (1977). Homosexuality and creativity. Journal of Homosexuality, 2(3), 261-267. http://dx.doi.org/10.1300/J082v02n03_09

Ellis, A. (1959). Homosexuality and creativity. Journal of Clinical Psychology, 15, 376-379. http://dx.doi.org/10.1002/1097-4679(195910)15:4<376::AID-JCLP2270150405>3.0.CO;2-T

Fassler, B. (1979). Theories of homosexualities as sources of Bloomsbury's androgyny. Signs, 5(2), 237-251. http://dx.doi.org/10.1086/493706

Fishkin, A. S., \& Johnson, A. S. (1998). Who is creative? Identifying children's creative abilities. Roeper Review, 21, 40-46. http://dx.doi.org/10.1080/02783199809553925

Gautam, M. (2001). Going the Wilde way. Homosexuality: Its impact on creativity and inclination towards creative pursuits. Creative Strategies, 2, 1-25.

Gedo, J. E. (1996). The artist and the emotional world. Columbia University Press.

Habibollah, N., Abdullah, R., Tengku Aiza, H., Sharir, J., \& Kumar, V. (2010). Relationship between creativity and academic achievement: A study of gender differences. Journal of American Science, 6(1), 181-190.

Hart, K. R. (2004). We're here, we're queer - and we're better than you: The representational superiority of gay men to heterosexuals on queer eye for the straight guy. The Journal of Men's Studies, 12(3), 241-253. http://dx.doi.org/10.3149/jms.1203.241

Hennessey, B. A. (1995). Social, environmental, and developmental issues and creativity. Educational Psychology Review, 7(2), 163-183. http://dx.doi.org/10.1007/BF02212492

Hennessey, B. A. (2003). The social psychology of creativity. Scadinavian. Journal of Educational Research, 47(3), 253- 271. http://dx.doi.org/10.1080/00313830308601

Kaufman, J. C. (2006). Self-reported differences in creativity by ethnicity and gender. Applied Cognitive Psychology, 20, 1065-1082. http://dx.doi.org/10.1002/acp.1255

Kaufman, J. C., Baer, J., Agars, M. D., \& Loomis, D. (2010). Creativity stereotype and the consensual assessment technique. Creativity Research Journal, 22(2), 200-205. http://dx.doi.org/10.1080/10400419.2010.481529

Khatena, J., \& Torrance, E. P. (1976). Manual for Khatena-Torrance Creative Perception Inventory. Chicago, IL: Stoelting

Khatena, J., \& Torrance, E. P. (1998). Khatena-Torrance Creative Perception Inventory: Instruction Manual. USA: Scholastic Tecting Service, Inc.

Konik, J., \& Crawford, M. (2004). Exploring normative creativity: Testing the relationship between cognitive $\begin{array}{lllll}\text { flexibility and sexual identity. Sex } & \text { Roles, }\end{array}$ http://dx.doi.org/10.1023/B:SERS.0000037885.22789.83

Lippa, R. A. (2005). Sexual orientation and personality. Annual Review of Sex Research, 16, 119-153.

Lippa, R. A. (2008). Sex differences and sexual orientation differences in personality: Findings from the BBC internet survey. Archives of Sexual Behavior, 37, 173-187. http://dx.doi.org/10.1007/s10508-007-9267-z

Norlander, T., Erixon, A., \& Archer, T. (2003). Psychological androgyny and creativity: Dynamics of gender-role and personality trait. Social Behavior and Personality, 28(5), 423-436. http://dx.doi.org/10.2224/sbp.2000.28.5.423 
Palaniappan, A. K. (1994). A study of creativity and achievement among Form Four Malaysian students. Unpublished Doctoral Dissertation. University of Malaya, Malaysia.

Palaniappan, A. K. (2007). Academic achievement of groups formed based on creativity and intelligence. Paper presented at the $13^{\text {th }}$ International Conference on Thinking.

Palaniappan, A. K. (2010). Creativity dimensions: Self and multi-talent perceptions across culture. In Dimension of Education. New Delhi: Gyan Publishing House.

Singh, A. A., \& Shelton, K. (2011). A content analysis of LGBTQ qualitative research in counseling: A ten-year review. Journal of Counseling and Development, 89, 217-226. http://dx.doi.org/10.1002/j.1556-6678.2011.tb00080.x

Stokinger, J. (1974). Toward a gay criticism. College English, 36(3), 303-311. http://dx.doi.org/10.2307/374841

Stolzfus, G., Nibbelink, B. L., Vredenburg, D., \& Thyrum, E. (2011). Gender, gender role, and creativity. Social Behavior and Personality, 39(3), 425-432. http://dx.doi.org/10.2224/sbp.2011.39.3.425

Torrance, E. P. (1993). Understanding creativity: Where to start? Psychological Inquiry, 4(3), $232-234$. http://dx.doi.org/10.1207/s15327965pli0403_17

Voorhis, R. V., \& Wagner, M. (2002). Among the missing: Content on lesbian and gay people in social work journals. Social Work, 47(4), 345-354. http://dx.doi.org/10.1093/sw/47.4.345

Whitley, B. E. (1990). The relationship of heterosexual's attributions for the causes of homosexuality to attitudes toward lesbian and gay men. Personality and Social Psychology Bulletin, 16, 369-377. http://dx.doi.org/10.1177/0146167290162016

Yarhouse, M. A. (2012). Integration in the study of homosexuality, GLBT issues, and sexual identity. Journal of Psychology and Theology, 40(2), 107-111. 